https://doi.org/10.31470/2706-7904-2020-15-217-220

\title{
ПСИХОЛІНГВІСТИЧНА СКЛАДОВА ФОРМУВАННЯ У ДІТЕЙ СТАРШОГО ДОШКІЛЬНОГО ВІКУ СТІЙКИХ УМІНЬ СТВОРЕННЯ РОЗПОВІДЕЙ ВСІХ ТИПІВ
}

\section{Psycholinguistic Component of Formation of Stable Skills of Creation of Stories of All Types in Children of Senior Preschool Age}

\author{
Oleksandr Savchyn \\ Senior Lecturer \\ Pereiaslav-Khmelnytskyi Hrihorii Skovoroda State Pedagogical University (Ukraine) \\ sam111@ukr.net \\ https://orcid.org/0000-0003-3994-5872
}

\begin{abstract}
Absrtact
The experience gained by the author during the approbation / implementation of "Author's motivational linguistic and pedagogical technology of forming stable skills in creating of different types stories by older preschool children» in PEI (preschool educational institutions), allows to state the real reason for ineffective mastery of different types storytelling in general and monological speech in particular, which lies in the lack of creating a psychologically favorable climate for inclusion of the each child into educational process, that has an extremely negative impact on its effectiveness in mastering and appropriate use of different types storytelling in everyday communication.

A separate problem for study and solution is the psycholinguistic component of stable skills formation in older preschool children for creating stories of all types in the implementation of the author's motivational linguistic and pedagogical technology in general and acquisition by students of skills to perform internal speech operations with external speech sounding of thought in particular.
\end{abstract}

Key words: mentor, tutor, motivator, story - presentation, story - instruction.

\section{Вступ \\ Introduction}

Активне мовлення дитини починається 3 мовленнєвого наслідування й $€$ ефективним за умов емфатичного мовлення (виразного, вимовленого у піднесеному тоні, емоційно) (Калмикова, 2016). Активне спілкування починається з розуміння 
дитиною мови та здатності висловлювати в індивідуальному мовленні власні наміри, бажання, прагнення (Богуш, 2005).

Дитина, у цьому віці, вже повинна вміти складати розповіді за картинками, про іграшки, передавати зміст почутих оповідань, переглянутих мультфільмів, фільмів, вистав, тематичні творчі розповіді, розповіді-етюди, мініатюри, 3 власного досвіду тощо (Калмикова, 2003).

Оволодіння різними типами розповіді повинно відбуватися на основі елементарних уявлень про структуру, функціональне призначення тексту, засоби образності, формування якостей самостійного зв'язного висловлювання: цільності, змістовності, логічної послідовності, образності, креативності.

Метою цього дослідження є успішне оволодіння дітьми старшого дошкільного віку стійкими уміннями продукувати розповіді всіх типів, через створення ефективної мовленнсвої ситуації (наявності теми, мети, місця, часу мовлення та адресата), психолого-педагогічної атмосфери, коли діти свідомо приймають участь у цілеспрямованому процесі оволодіння навичками й уміннями використання мови у спеціально організованому мовленнєво-педагогічному середовищі для засвоєння соціально-культурного досвіду, норм рідної мови, довільного й усвідомленого опанування процесуальності мовлення, встановлення доцільної вербальної комунікації (Калмикова, 2008).

Окремою проблемою для вирішення є психолінгвістична складова щодо формування у дітей старшого дошкільного віку стійких умінь створення розповідей всіх типів взагалі та набуття вихованцями навички внутрішньо мовленнєвих операцій із зовнішньо мовленнєвим озвученням власної думки зокрема (Баєв, 1966).

\section{Методи та методики дослідження}

Methods and Techniques of the Research

«Авторська мотиваційна лінгво-педагогічна технологія формування стійких умінь створення розповідей різних типів дітьми старшого дошкільного віку» $\epsilon$ цілісною системою дидактичних категорій (мета, завдання, зміст, методи, форми, засоби), що організовує та контролює процес формування у старших дошкільників різнотипного розповідного мовлення при створенні фасилітаційного середовища допомоги, полегшення, сприяння - організації взаємоповажної атмосфери довіри однолітків між собою та 3 педагогом, при якій думка кожного (навіть помилкова) буде почута, не зважаючи на те, чи потребує вона грамотної корекції. Дорослий, при цьому, не є лектором, а виконує роль ментора (порадника щчодо індивідуального 
Psycholinguistics in a Modern World - 2020. Proceedings of the 15th International Scientific and Practical Conference (Pereiaslav-Khmelnytskyi, 22-23 October, 2020)

зростання особистості), тьютора (наставника, репетитора), коуча (помічником $у$ досягненні мети), мотиватора (того, хто спонукає до дій).

Критеріями та показникми сформованості умінь створювати старшими дошкільнятами різнотипні розповіді є когнітивний (сформованість знань про особливості використання розповідей всіє типової гами при комунікуванні), мотиваційно-ціннісний (вмотивованість до оволодіння стійкими уміннями майстерно продукувати розповіді різноманітної типізації, включно $з$ новими типами розповідей (розповідь-інструкиія та розповідь-презентація), технологічнорезультативний (володіння навичками аналізу інформації, виокремлення головного та синтезування рішень, продукуючи доречні типи розповідей, включно 3 розповідями-презентаціями та розповідями-інструкиіями, як ефективного інструменту переконання.

Під розповідљю-презентацією слід розуміти «усний виклад інформації про позитивні переваги живої/неживої природи, предметів/явищ у побутово-соціальному середовищі, щзо неодмінно сприятиме особистості в ї̈ адаптації, комунікуванні та самоствердженні в суспільстві», а під розповіддю-інструкцією пропонується розуміти «усний виклад інформації про дї у часі та просторі, яка містить перелік конкретних покрокових правил, дотримання яких гарантує успіх щзодо досягнення поставленої меті» (Савчин, 2018).

Цікавість, емоційну насиченість процесу навчання покликана забезпечити квестова/ігрова атмосфера навчання вихованців створювати розповіді всіх типів, закріплюючи ці навички в стійкі уміння (квест - дослідження світу у вигляді пригодницької гри, шляхом розгадування головоломок $і$ завдань, щзо вимагають розумових зусиль від учасників).

\section{Результати}

\section{Results}

Отримані результати апробації/втілення «Авторської мотиваційної лінгвопедагогічної технології формування стійких умінь створення розповідей різних типів дітьми старшого дошкільного віку» в закладах дошкільної освіти, дозволяють констатувати справжню причину неефективного опанування дошкільниками різнотипового розповідання зокрема та монологічного мовлення взагалі, яка криється в ігноруванні психолінгвістичної складової та відсутності створення психологічно сприятливого клімату щодо включення кожної дитини в навчально-виховний процес, що вкрай негативно впливає на їі якісний результат формування у дітей старшого дошкільного віку стійких умінь створення розповідей всіх типів. 


\section{Висновки \\ Conclusions}

Запорукою успіху «Авторської мотиваційної лінгво-педагогічної технології формування стійких умінь створення розповідей різних типів дітьми старшого дошкільного віку» $є$ створення в дитячому середовищі фасилітаційної атмосфери взаємоповаги, підтримки одне одного, командно-групових, квестових, творчопошукових методів, що дозволяє зробити навчальний процес цікавим, забезпечити емоційну включеність дітей, активізувати їх пізнавальну діяльність, розумові та мовленнєві здібності, реалізуючи особистісно-орієнтований, диференційований підхід в навчанні, коли дорослий $є$ надійним порадником у соціалізації дитини, іiї навчанні конструктивно вирішувати життєві виклики.

\section{Література \\ References}

Баєв, Б.Ф. (1966). Психологія внутрішнього мовлення. Київ: Радянська школа.

Богуш, А.М. (2005). Дошкільна лінтводидактика. (Хрестоматія). Київ: СЛОВО.

Калмикова, Л.О. (2003). Формування мовленнєвих умінь і навичок у дітей: психологічний та лінгвістичний аспекти. Київ: НМЦВО.

Калмикова, Л.О. (2008). Психологія формування мовленнєвої діяльності у дітей дошкільного віку. (Монографія). Київ: Фенікс.

Калмикова, Л.О. (2016). Формування у дітей старшого дошкільного віку мовленнсвої діяльності: діагностично-розвивальний комплекс. Київ: Видавничий дім «Слово».

Савчин, О.М. (2018). Формування у дітей п'ятирічного віку умінь будувати розповіді всіх типів. HUMANITARIUM. Серія: Педагогіка, 2(2), 122-130. 